\title{
Papers
}

\section{Outcome of case finding among relatives of patients with known heterozygous familial hypercholesterolaemia}

\author{
D Bhatnagar, J Morgan, S Siddiq, M I Mackness, J P Miller, P N Durrington
}

\begin{abstract}
Objectives To assess the feasibility of detecting new cases of heterozygous familial hypercholesterolaemia by using a nurse led genetic register.

Design Case finding among relatives of patients with familial hypercholesterolaemia.

Setting Two lipid clinics in central and south Manchester.

Subjects 259 (137 men and 122 women) probands and 285 first degree relatives.

Results Of the 200 first degree relatives tested, 121 $(60 \%)$ had inherited familial hypercholesterolaemia. The newly diagnosed patients were younger than the probands and were generally detected before they had clinically overt atherosclerosis. Concentrations of serum cholesterol were, respectively, 8.4 (1.7 SD) $\mathrm{mmol} / \mathrm{l}$ and 8.1 (1.9 SD) mmol/l in affected men and women and $5.6(1.0 \mathrm{SD}) \mathrm{mmol} / \mathrm{l}$ and $5.6(1.1 \mathrm{SD})$ $\mathrm{mmol} / \mathrm{l}$ in unaffected men and women. Screening for risk factors as recommended in recent guidelines for coronary heart disease prevention would have failed to identify most of the affected relatives in whom hypertension, diabetes mellitus, cigarette smoking, and obesity were uncommon.

Conclusions By performing cholesterol tests on 200 relatives, 121 new patients with familial

hypercholesterolaemia were discovered. Because 1 in 500 people in the UK are affected by this condition, to detect a similar number by population screening over 60000 tests would be required, and only a few of these patients would have been detected had cholesterol testing been restricted to those with other risk factors for coronary heart disease. A case exists for organising a genetic register approach, linking lipid clinics nationally.
\end{abstract}

\section{Introduction}

Familial hypercholesterolaemia in its heterozygous form occurs in around 1 in 500 people in Europe and North America, making it the most common potentially lethal genetic disorder. The characteristic clinical syndrome in adulthood comprises an increased serum cholesterol concentration, tendon xanthomas, and premature coronary heart disease, the median age of onset for coronary heart disease being around 50 years in men and 59 in women. ${ }^{12}$ Statin treatment and the opportunity for prompt access to cardiological services for patients with familial hypercholesterolaemia seem to have improved survival. ${ }^{3}$ In trials using coronary angiography, cholesterol lowering treatment is at least as effective in patients with familial hypercholesterolaemia as it is in other types of patients with coronary disease. Most of the potential 100000 patients with familial hypercholesterolaemia in the United Kingdom are probably undiagnosed, because only a small proportion attend lipid clinics. ${ }^{6}$ The same is also likely to be true in other countries. ${ }^{7}$ Often the clinical syndrome of familial hypercholesterolaemia is due to a mutation of the low density lipoprotein receptor. However, because more than 200 different mutations have been described in association with the syndrome, ${ }^{8}$ genetic testing is not currently a feasible means of establishing the diagnosis, except perhaps in families with a known mutation or in societies with a more limited number of mutations due to a founder gene's effects or where consanguinity is common..$^{9-11}$ A previous report based on our clinic population showed a prevalence of only $3.9 \%$ for the most common low density lipoprotein receptor gene mutation. ${ }^{12}$

It is generally agreed that screening the population for high cholesterol concentrations should be undertaken only as part of a multifactorial approach for the detection of people with a high coronary risk so that cholesterol lowering and antihypertensive treatments can be used in the most cost effective way. ${ }^{13}$ Familial hypercholesterolaemia, however, seems to be a condition in which a single risk factor (high cholesterol from birth) often leads to an absolute coronary risk in the range for statin treatment well before middle age. ${ }^{13}$ We aimed to assess the possibility of using a genetic register method to diagnose new cases of familial hypercholesterolaemia, which has the potential to be adopted nationally.

\section{Participants and methods}

Probands aged 18 years or over attending two adjacent lipid clinics (Manchester Royal Infirmary and University Hospital of South Manchester) for the first time between 1987 and 1998 were identified by using the Simon Broome criteria for the diagnosis of familial hypercholesterolaemia. ${ }^{14}$ For patients aged over 16 years these are serum cholesterol concentrations exceeding $7.5 \mathrm{mmol} / \mathrm{l}$ (or low density lipoprotein cholesterol concentrations exceeding $4.9 \mathrm{mmol} / \mathrm{l}$ ) with ten-

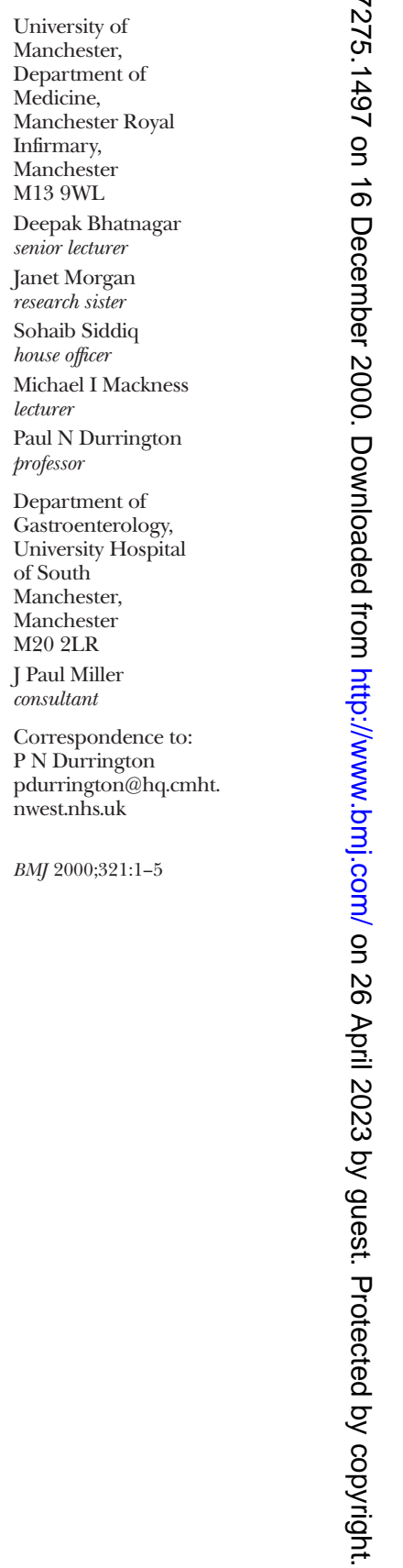


don xanthomas present in the patient or in first degree or second degree relatives. In none of our probands did the diagnosis depend on tendon xanthomas in a second degree relative.

Nurses were trained to identify corneal arcus, xanthelasmas, and tendon xanthomas and to administer a questionnaire to probands and their first degree relatives that inquired about the presence of other risks factors for coronary and cardiovascular disease already evident. A detailed family history was recorded for the probands, including addresses and, wherever possible, telephone numbers of any first degree relatives. To do this, special time was set aside from routine clinic visits, and the reason for this was explained to the patients in advance. The risk factors recorded were hypertension requiring drug treatment, cigarette smoking, and diabetes mellitus diagnosed by a doctor. Coronary heart disease was recorded as previous acute myocardial infarction diagnosed in hospital, angina of effort diagnosed by a doctor, or coronary artery bypass surgery. A previous diagnosis of stroke by a doctor was also recorded, and the possible presence of intermittent claudication was sought by using the Rose questionnaire.

First degree relatives were sent a personalised, standard letter explaining the reason for suspecting that they might have familial hypercholesterolaemia, its importance, and the method of diagnosis. A daytime telephone number was provided for inquiries and to inform the nurse of whether they preferred to visit her or to be seen at their general practice. If they chose to see the nurse, they attended the Manchester Royal Infirmary, where the questionnaire was completed and a fasting blood sample taken. Otherwise the questionnaire was sent by post and the blood sample was taken at their general practice and sent to the nurse in Manchester. The general practitioners of these relatives received a letter explaining familial hypercholesterolaemia, its clinical features (including coloured photographs of corneal arcus, xanthelasmas, and tendon xanthomas in the Achilles tendons and on the dorsum of the hands), and details of the register, together with a blood specimen container, venepuncture equipment, and secure prepaid packaging in which to return the blood sample by first class post.

The results of the relatives' blood tests for serum cholesterol concentrations were sent to the general practitioners with a letter explaining why the test had been done and the importance of the result. The location of the nearest lipid clinic was provided when the test gave a positive result. General practitioners also had the option of treating newly diagnosed patients themselves, with advice, if requested. None, however, chose to do this, preferring to refer the patient to hospital. Relatives with newly diagnosed familial hypercholesterolaemia were sent a letter indicating that their cholesterol concentration was increased and suggesting that they make an appointment to see their general practitioner. Counselling was also available by telephone, and the general practitioner was given the same telephone number should additional information be required. Relatives not inheriting familial hypercholesterolaemia were also informed and the importance of that explained; they were also invited to telephone for further explanation.
The research ethics committees at both hospitals considered that the register was an extension of usual clinical practice.

Concentrations of serum cholesterol, high density lipoprotein cholesterol, and triglycerides were measured enzymatically by the CHOD-PAP and GPOPAP methods, respectively (both from Roche Diagnostics, Lewes). High density lipoprotein was isolated from serum by heparin manganese precipitation of the other lipoproteins, and the concentration of low density lipoprotein cholesterol was calculated using the Friedewald formula. ${ }^{15}$ The concentration of serum apolipoprotein B was determined by using rate nephelometry with the Beckman Array and reagents (Beckman Instruments, Palo Alto, CA) and serum Lp(a) lipoprotein concentration by an immunoradiometric assay (Mercodia, Uppsala, Sweden). At the time of referral some probands were already receiving treatment with cholestyramine or statins. Despite this, in every case the Simon Broome criteria for diagnosis were satisfied. The contemporary laboratory values are quoted.

\section{Statistics}

Variables with a Gaussian distribution were compared with Student's $t$ test and those that were non-Gaussian with the Mann-Whitney U test. Frequency distributions were compared with $\chi^{2}$ tests. We considered probabilities $\leqslant 0.05$ as significant.

\section{Results}

\section{Compliance of probands and availability of} relatives

Of 262 probands identified, all but three agreed to participate. Thus 259 (99\%) (137 men and 122 women) provided details of their family tree. Of these, 216 $(83 \%)$ had at least one living first degree relative, the total number of whom was estimated to be 285 . Of these, 205 (72\%) were tested. Of the 80 not tested, 25 were already known to have familial hypercholesterolaemia, 26 considered themselves to live too far away (seven outside the United Kingdom), 18 refused to participate (seven had needle phobia), six agreed but did not attend, and five were infirm. In $26 \%$ of cases more than one relative of a proband was tested. Most relatives $(98 \%)$ preferred to visit the nurse, often accompanied by the proband.

\section{Detection of new cases}

Of the 205 relatives tested, the results for cholesterol concentration were available in 200, of whom 121 (60\%; 46 men and 75 women) proved positive (heterozygotes by definition) and 79 (40\%; 37 men and 42 women) had serum cholesterol concentrations less than $7.5 \mathrm{mmol} / \mathrm{l}$. Male probands were less likely to provide a cooperative relative than were female probands. Thus 137 male probands yielded 46 new cases (ratio of probands to new cases 3.0:1), whereas 122 female probands produced 75 new cases (ratio 1.6:1). The difference in the number of new cases detected for male and female probands was significant $(\mathrm{P}<0.0005)$.

\section{Clinical characteristics of probands and relatives}

Tendon xanthomas were present in $91 \%$ of male and $87 \%$ of female probands, whereas only $26 \%$ of the 
Table 1 Age, body mass index, physical signs, and concentrations of lipids and lipoproteins in familial hypercholesterolaemia probands and their affected and unaffected relatives. Values in parentheses are 95\% copnfidence intervals unless stated otherwise

\begin{tabular}{|c|c|c|c|c|c|c|}
\hline & \multicolumn{3}{|c|}{ Men } & \multicolumn{3}{|c|}{ Women } \\
\hline & \multirow[b]{2}{*}{ Probands ( $n=137$ ) } & \multicolumn{2}{|c|}{ Relatives } & \multirow[b]{2}{*}{ Probands ( $\mathrm{n}=122$ ) } & \multicolumn{2}{|c|}{ Relatives } \\
\hline & & Affected $(n=46)$ & Unaffected $(n=37)$ & & Affected ( $n=75)$ & Unaffected $(\mathrm{n}=42)$ \\
\hline Mean (SD) age & $45.0(11.4)$ & $34.5(14.8)^{\star * *}$ & $26.7(13.2)^{\star \star *}$ & $48.9(12.6)$ & $38.2(18.5)^{\star \star \star *}$ & $36.7(16.2)^{\star * \star}$ \\
\hline Body mass index $\left(\mathrm{kg} / \mathrm{m}^{2}\right)$ & 25.2 (24.7 to 25.7 ) & 25.1 (23.9 to 26.3) & 24.8 (23.5 to 26.1$)$ & 24.6 (24.0 to 25.3 ) & 23.6 (22.3 to 24.9$)$ & 24.6 (22.9 to 26.3 ) \\
\hline Corneal arcus (\%) & $49(41$ to 58$)$ & $17(8 \text { to } 31)^{\star \star *}$ & $3(0 \text { to } 14)^{* * *}$ & 49 (40 to 58$)$ & $17(10 \text { to } 28)^{\star * *}$ & $2(0 \text { to } 13)^{\star \star \star}$ \\
\hline Xanthelasmas (\%) & 21 (14 to 28$)$ & $2(0 \text { to } 12)^{\star \star \star}$ & $0(0 \text { to } 9)^{* \star *}$ & 25 (18 to 34$)$ & $16(9 \text { to } 26)^{\star \star \star \star}$ & $0(0 \text { to } 8)^{\star \star \star}$ \\
\hline Tendon xanthomas (\%) & 91 (83 to 99) & $26(14 \text { to } 41)^{\star \star \star}$ & $0(0 \text { to } 9)^{\star \star *}$ & 87 (81 to 93) & $19(11 \text { to } 29)^{\star \star \star}$ & $0(0 \text { to } 8)^{\star \star \star}$ \\
\hline $\begin{array}{l}\text { Median (interquartile range) serum } \\
\text { triglyceride }(\mathrm{mmol} / \mathrm{l})\end{array}$ & $1.67(1.11-2.30)$ & $1.75(1.00-2.61)$ & $1.20(0.87-1.67)$ & $1.09(0.83-1.56)$ & $1.02(0.76-1.52)$ & $1.02(0.71-1.41)$ \\
\hline $\begin{array}{l}\text { Serum low density lipoprotein } \\
\text { cholesterol (mmol/l) }\end{array}$ & $6.0(5.6$ to 6.4$)$ & 5.3 (4.9 to 5.8$)$ & $3.1(2.8 \text { to } 3.4)^{\star * *}$ & $5.5(5.1$ to 5.9$)$ & $6.0(5.6$ to 6.4$)$ & $3.2(3.0 \text { to } 3.5)^{\star \star *}$ \\
\hline $\begin{array}{l}\text { Serum high density lipoprotein } \\
\text { cholesterol (mmol/l) }\end{array}$ & 1.24 (1.13 to 1.35$)$ & 1.23 (1.11 to 1.35$)$ & $1.53(1.36 \text { to } 1.70)^{\star \star *}$ & 1.59 (1.50 to 1.68$)$ & 1.45 (1.36 to 1.54$)$ & 1.54 (1.38 to 1.70$)$ \\
\hline Apolipoprotein B (g/l) & 1.44 (1.38 to 1.50$)$ & 1.45 (1.32 to 1.58$)$ & $0.94(0.85 \text { to } 1.03)^{\star \star *}$ & 1.51 (1.42 to 1.60$)$ & 1.48 (1.38 to 1.58$)$ & $0.92(0.85 \text { to } 0.99)^{\star \star *}$ \\
\hline $\begin{array}{l}\text { Median (interquartile range) } L p(a) \\
\text { lipoprotein }(\mathrm{g} / \mathrm{l})\end{array}$ & $0.29(0.119-0.735)$ & $0.148(0.064-0.562)^{*}$ & $0.086(0.038-0.353)^{\star \star}$ & $0.479(0.196-0.821)$ & $\begin{array}{c}0.202 \\
(0.067-0.441)^{\star * *}\end{array}$ & $0.086(0.053-0.386)^{\star * *}$ \\
\hline
\end{tabular}

${ }^{*} \mathrm{P}<0.05,{ }^{* *} \mathrm{P}<0.01,{ }^{* * *} \mathrm{P}<0.005$ compared with probands.

newly diagnosed men and 19\% of the newly diagnosed women possessed them $(\mathrm{P}<0.0005)$ (table 1$)$. This was probably because of the younger age of the newly diagnosed relatives. It is notable that many probands had still not developed either corneal arcus or xanthelasmas at a stage of their disease when tendon xanthomas were evident. In neither the probands nor the affected and unaffected relatives was obesity prevalent. Male and female probands and newly diagnosed relatives with familial hypercholesterolaemia had increased concentrations of cholesterol, low density lipoprotein cholesterol, and apolipoprotein B, and affected men (probands and newly diagnosed) also had lower concentrations of serum high density lipoprotein cholesterol than did their unaffected relatives. Serum and low density lipoprotein cholesterol concentrations were similar in probands and affected relatives despite some probands receiving cholesterol lowering treatment, albeit generally with low doses of statin or cholestyramine when they were first studied. It was considered unethical to discontinue these drugs for the purpose of this investigation. It is possible that the cholesterol concentrations when the probands were not receiving treatment would have been higher than in their younger affected relatives, because of the increase in serum cholesterol concentration that occurs in middle age. $\operatorname{Lp}(\mathrm{a})$ lipoprotein was also significantly lower in male and female affected and unaffected relatives than it was in probands. The median values for unaffected men and women were similar to those in a normal healthy population previously studied by us. ${ }^{16}$ The affected relatives were intermediate with respect to their serum $\mathrm{Lp}$ (a) lipoprotein concentration. We have previously reported that when matched for age, probands and affected relatives have similar concentrations of Lp(a) lipoprotein. ${ }^{17}$ Thus our present finding may lend some support to the view that $\mathrm{Lp}$ (a) lipoprotein concentration increases with advancing arterial disease, which would explain its association with coronary heart disease in some case studies. ${ }^{18}$

Cardiovascular disease was significantly more common in probands than it was in newly diagnosed affected relatives and in unaffected relatives, particularly coronary heart disease (angina, myocardial infarction, or coronary artery bypass grafting, or combinations of these; table 2). A low prevalence of cardiovascular risk factors was found apart from increased concentrations of cholesterol in either the probands or

Table 2 Prevalence of major cardiovascular risk factors and diseases among probands with familial hypercholesterolaemia and their affected and unaffected relatives. Values are percentages ( $95 \%$ confidence intervals)

\begin{tabular}{|c|c|c|c|c|c|c|}
\hline \multirow[b]{3}{*}{ Risk factor } & \multicolumn{3}{|c|}{ Men } & \multicolumn{3}{|c|}{ Women } \\
\hline & \multirow[b]{2}{*}{ Probands $(n=137)$} & \multicolumn{2}{|c|}{ Relatives } & \multirow[b]{2}{*}{$\begin{array}{l}\text { Probands } \\
(\mathrm{n}=122)\end{array}$} & \multicolumn{2}{|c|}{ Relatives } \\
\hline & & Affected $(n=46)$ & $\begin{array}{l}\text { Unaffected } \\
(\mathrm{n}=37)\end{array}$ & & Affected $(\mathrm{n}=75)$ & $\begin{array}{l}\text { Unaffected } \\
(\mathrm{n}=42)\end{array}$ \\
\hline Cigarette smoking & $13(8$ to 20$)$ & $28(16$ to 43$)$ & 6 (1 to 18$)$ & 17 (11 to 25$)$ & 12 (6 to 22) & 19 (9 to 34$)$ \\
\hline Hypertension & $2(0$ to 6$)$ & 4 (0 to 12$)$ & 6 (1 to 18$)$ & 4 (1 to 10$)$ & $0(0$ to 5$)$ & $0(0$ to 8$)$ \\
\hline Diabetes mellitus & $<1(0$ to 4$)$ & $0(0$ to 8$)$ & $0(0$ to 9$)$ & $<1(0$ to 5$)$ & $0(0$ to 5$)$ & $0(0$ to 8$)$ \\
\hline Angina & $21(14 \text { to } 28)^{*}$ & 7 (1 to 18$)$ & $0(0$ to 9$)$ & $17(11 \text { to } 25)^{\star}$ & 7 (2 to 15$)$ & $2(0$ to 13$)$ \\
\hline Myocardial infarction & $18(12 \text { to } 25)^{\star *}$ & 4 (0 to 12$)$ & $0(0$ to 9$)$ & $9(5 \text { to } 16)^{\star}$ & $1(0$ to 7$)$ & $0(0$ to 8$)$ \\
\hline Coronary artery bypass grafting & $27(19 \text { to } 35)^{\star \star}$ & 7 (1 to 18$)$ & $3(0$ to 14$)$ & $7(11 \text { to } 25)^{*}$ & $0(0$ to 5$)$ & $0(0$ to 8$)$ \\
\hline Coronary heart disease $\dagger$ & $44(35 \text { to } 53)^{\star *}$ & 11 (4 to 24$)$ & $0(0$ to 9$)$ & $26(19 \text { to } 35)^{* *}$ & 8 (3 to 17$)$ & $2(0$ to 13$)$ \\
\hline Stroke & $7(3 \text { to } 13)^{\star}$ & 7 (1 to 18$)$ & $3(0$ to 14$)$ & $6(2 \text { to } 12)^{\star}$ & $0(0$ to 5$)$ & $0(0$ to 8$)$ \\
\hline Coronary heart disease or stroke, or both & $44(35 \text { to } 53)^{\star \star}$ & 15 (6 to 29 ) & $3(0$ to 14$)$ & $28(21 \text { to } 37)^{\star \star}$ & 9 (4 to 18$)$ & $2(0$ to 13$)$ \\
\hline Intermittent claudication $\ddagger$ & $12(7 \text { to } 19)^{\star}$ & 4 (0 to 12$)$ & $0(0$ to 9$)$ & $16(10 \text { to } 25)^{\star}$ & $11(5$ to 20$)$ & 5 (1 to 16$)$ \\
\hline Cardiovascular disease§ & $51(41 \text { to } 59)^{* * *}$ & 20 (9 to 34$)$ & $3(0$ to 14$)$ & $41(32 \text { to } 50)^{\star \star * \star}$ & 20 (12 to 31$)$ & $5(1$ to 16$)$ \\
\hline
\end{tabular}

${ }^{*} \mathrm{P}<0.01,{ }^{* *} \mathrm{P}<0.001,{ }^{* * *} \mathrm{P}<0.0001$ compared with affected or unaffected relatives $\left(\chi^{2}\right.$ test $)$.

$\dagger$ Angina, myocardial infarction, or coronary artery bypass grafting, or a combination of these.

†Rose questionnaire.

$\S$ Coronary heart disease, stroke, or intermittent claudication, or a combination of these. 
their newly diagnosed relatives (table 2). Serum cholesterol concentrations would thus be unlikely to be measured in newly diagnosed relatives in the United Kingdom except in those with overt coronary heart disease. Furthermore, the average coronary risk in the newly diagnosed relatives, according to the Framingham risk equation on which the UK, American, and European guidelines are based, ${ }^{13}$ was $6 \%$ over 10 years for men and 3\% over 10 years for women.

\section{Discussion}

The investigation indicated that a genetic register based on 262 probands with familial hypercholesterolaemia attending a lipid clinic could identify 121 new cases. Heterozygous familial hypercholesterolaemia affects around 1 in 500 of the general population. Thus to attempt to identify 121 new cases by universal population screening for high serum cholesterol concentrations would require more than 60000 cholesterol tests, whereas only 200 tests were necessary in the present study. Selective screening for high cholesterol concentrations by confining cholesterol testing to patients in whom other cardiovascular risk factors or coronary heart disease are present would have missed all of the cases identified in our investigation, with the exception of a small proportion with established coronary heart disease or hypertension. Furthermore, had a detailed family history been obtained from newly diagnosed relatives with familial hypercholesterolaemia discovered in this study, it is likely that additional first degree relatives could have been discovered who could be tested, and so on, amplifying the number of new cases detected. Applying a similar method in other lipid clinics nationally would give access to new probands and could lead to a considerable increase in the number of known heterozygotes for familial hypercholesterolaemia.

The typical male and female heterozygote discovered in the present investigation would seem to have a coronary risk of only $6 \%$ or $3 \%$, respectively, over the next 10 years, if calculated according to the Framingham risk equation on which current guidelines for coronary prevention are based, ${ }^{13}$ whereas it is known from other investigations that they were likely to develop clinical coronary heart disease at a similar age to their probands, ${ }^{2}$ which means their true risk was several times greater. The discovery of increased cholesterol concentrations in a heterozygote for familial hypercholesterolaemia therefore is not likely to lead to appropriate treatment unless the clinician assessing the importance of the finding is aware that the patient has familial hypercholesterolaemia rather than polygenic hypercholesterolaemia. Our strategy ensures that this is the case.

In the present investigation relatives were required to fast. This was so that their concentration of fasting serum triglycerides could be determined, which we needed to calculate the concentration of low density lipoprotein cholesterol. This would not be necessary in practice, because the total serum cholesterol concentration that is unaffected by fasting ${ }^{15}$ provides enough biochemical information for the Simon Broome definition of familial hypercholesterolaemia. It is, however, important to realise that this definition does not rely simply on a cholesterol concentration exceeding
$7.5 \mathrm{mmol} / \mathrm{l}^{3}$ Such a concentration is relatively common in Britain, where it is around the 95th centile for the general population of similar age to the newly diagnosed relatives. ${ }^{19}$ A serum cholesterol concentration exceeding $7.5 \mathrm{mmol} / \mathrm{l}$ generally only indicates familial hypercholesterolaemia when it occurs in a patient related to an individual with definite familial hypercholesterolaemia, established as in our study by the presence of tendon xanthomas. Tendon xanthomas are exceedingly rare, except in familial hypercholesterolaemia, occurring otherwise only in phytosterolaemia and cerebrotendinous xanthomatosis. ${ }^{20}$ Patients with serum cholesterol concentrations of $7.5 \mathrm{mmol} / \mathrm{l}$ or even higher and no other cardiovascular risk factors, who do not have familial hypercholesterolaemia, are usually at much lower risk than heterozygotes for familial hypercholesterolaemia, particularly at the comparatively young age of the new cases of familial hypercholesterolaemia discovered in our study: they would thus seldom require treatment with statins. Again our strategy of screening only relatives of probands with familial hypercholesterolaemia ensures that inappropriate treatment and advice is not offered to people with less severe syndromes associated with hypercholesterolaemia. Conceivably some $5 \%$ of relatives of probands would have increased cholesterol concentrations due to some other cause, but this would introduce only a small error in our conclusions.

The finding that male probands were less likely to provide an affected relative than were female probands was probably because men were less likely to provide sufficient details for a relative to be traced, perhaps because their wives write the Christmas cards. A possible improvement to the present strategy might therefore be to ensure that wives are, if possible, present when male probands are interviewed.

The high prevalence of cardiovascular disease in probands is likely to be the result of the older age of the probands compared with that of the newly diagnosed relatives, and because their hypercholesterolaemia was discovered as the consequence of presenting with vascular symptoms. It has previously been reported that the age of onset of coronary heart disease with symptoms is similar in affected first degree relatives within individual families. ${ }^{2}$ The present findings thus suggest that this method of detecting new cases often identifies them before vascular disease is clinically overt which, given the mortality associated with a first myocardial infarction (around 30\% $\%^{21}$ ) and the subsequent morbidity, is a potentially important advantage. The Rose questionnaire probably overestimates the prevalence of intermittent claudication, but its higher relative frequency in probands compared with newly diagnosed relatives is likely to be genuine.

It has been calculated that the cost per life year gained from cholesterol reduction in familial hypercholesterolaemia is similar to that in patients after acute myocardial infarction, which is generally considered to be highly cost effective: more so, for example, than the cost of a generic thiazide to treat hypertension. ${ }^{22}$ There are potentially detrimental effects of screening. ${ }^{23}$ Our approach avoids the adverse effects caused by screening of the general population, leading to the discovery of huge numbers of asymptomatic people with more common less severe hypercholesterolaemia in which the health gain from such knowledge may be 


\section{What is already known on this topic}

Familial hypercholesterolaemia, comprising an increased serum cholesterol concentration, tendon xanthomas, and premature coronary heart disease, occurs in 1 in 500 people in Europe and North America

The high cholesterol concentrations often lead to an absolute coronary risk in the range for statin treatment well before middle age

\section{What this paper adds}

When contacted by specially trained nurses, most of the relatives of known patients with familial hypercholesterolaemia wanted their cholesterol concentration measured

Most patients were diagnosed before the clinical onset of coronary heart disease, which would rarely have been the case during a screening approach for multiple risk factors

minimal. Furthermore, although our decision not to employ DNA methods for the detection of familial hypercholesterolaemia was pragmatic, it meant that our approach also avoided the potential psychological harm caused by DNA testing. ${ }^{1024}$ Discovery of familial hypercholesterolaemia by case detection, however, as in the present study, probably has relatively brief adverse psychological effects, ${ }^{24}$ but such reassuring findings have generally been reported when counselling was available. It is likely that such counselling will be most effective when provided by healthcare workers who have frequent contact with patients with familial hypercholesterolaemia, and this is another potential advantage of the detection of new cases of familial hypercholesterolaemia through established lipid clinics using the genetic register approach reported here.

We thank Ms C Price for preparing the manuscript and Sisters Mary Brady, Pat Lockely, and Morag Ravenscroft for additional nursing support. Copies of the standard letters to relatives and general practitioners are available from PND.

Contributors: PND and DB conceived the study, secured its funding, designed the protocol, and supervised its execution. JM carried out most of the patient interviews and counselling. She helped to collate the results with SS, who together with DB, performed the statistical analyses. PND and JPM have clinical responsibility for the probands. MIM was responsible for the biochemical analyses. PND wrote the first draft of the paper after which all authors contributed to the final manuscript. PND and $\mathrm{DB}$ will act as guarantors for the paper.

Funding: This study was supported by an NHS Research and Development grant (PS004, North West Regional Health Authority) and the NHS Research and Development Levy.

Competing interests: None declared.
1 Goldstein JL, Hobbs HH, Brown MS. Familial hypercholesterolemia. In Scriver CR, Beaudet AL, Sly WS, Valle D, eds. The metabolic and molecular bases of inherited disease, 7th ed. New York: McGraw-Hill 1995:1981-2030.

2 Heiberg A, Slack J. Family similarities in the age at coronary death in familial hypercholesterolaemia. BMJ 1977;ii:493-5.

3 Scientific Steering Committee on behalf of the Simon Broome Register Group. Mortality in treated heterozygous familial hypercholesterolaemia implications for clinical management. Atherosclerosis 1999;142:105-12.

4 Kane JP, Malloy MJ, Ports TA, Phillips NR, Diehl JC, Harel RJ. Regression of coronary atherosclerosis during treatment of familial hypercholesterolemia with combined drug regimens. JAMA 1990;264:3007-12.

5 Thompson GR, Maher VMG, Matthews S, Kitano Y, Neuwirth C, Shortt $\mathrm{MB}$, et al. Familial hypercholesterolaemia regression study: a randomised trial of low-density-lipoprotein apheresis. Lancet 1995;345:811-6.

6 Laker MF, Reckless JPD, Betteridge DJ, Durrington PN, Miller JP, Nicholls DP, et al. Facilities for the management of patients with lipid disorders in the United Kingdom: results of the British Hyperlipidaemia Association survey. Heart Trends 1991;23:147-9.

7 Williams RR, Schumacher C, Barlow GJ, Hunt SC, Ware JL, Pratt M, et al. Documented need for more effective diagnosis and treatment of familial hypercholesterolaemia according to data from 502 heterozygotes in Utah. Am J Cardiol 1993;72:18-24D.

8 Hobbs HH, Brown MS, Goldstein JL. Molecular genetics of the LDL receptor gene in familial hypercholesterolemia. Hum Mutat 1992;1:44566.

9 Graadt von Roggen F, van der Westhuyzen DR, Marais AD, Gevers W, Coetzee GA. LDL receptor founder mutations in Afrikaaner familial hypercholesterolemic patients. A comparison of two geographical areas. Hum Genet 1991;88:204-8.

10 Humphries SE, Galton D, Nicholls P. Genetic testing for familial hyperc holesterolaemia: practical and ethical issues. OJ Med 1997;90:169-81.

11 Kastelein JJ. South African founder mutations in the low-density lipoprotein receptor gene causing familial hypercholesterolaemia in the Dutch population. Hum Genet 1993;92:567-70.

12 Talmud P, Tybjaerg-Hansen A, Bhatnagar D, MBewu AD, Durrington PN, Miller JP, et al. Screening for specific mutations in patients with a clinical diagnosis of familial hypercholesterolaemia. Atherosclerosis 1991;89:13742 .

13 Wood D, Durrington PN, Poulter N, McInnes G, Rees A, Wray R. Joint British recommendations on prevention of coronary heart disease in clinical practice. Heart 1998;80(suppl 2):1-29S.

14 Steering Committee of the Simon Broome Register Group. Risk of fatal coronary heart disease in familial hypercholesterolaemia. $B M J$ 1991;303:893-6.

15 Mackness MI, Durrington PN. Lipoprotein separation and analysis for clinical studies. In: Converse CA, Skinner ER, eds. Lipoprotein analysis. A practical approach. Oxford: Oxford University Press, 1992.

16 Bhatnagar D, Anand S, Durrington PN, Patel DJ, Wander GS, Mackney MI, et al. Coronary risk factors in people from Indian subcontinent living in West London and their siblings in India. Lancet 1995;345:405-9.

17 MBewu AD, Bhatnagar D, Durrington PN, Hunt L, Ishola M, Arrol S, et al. Serum lipoprotein (a) in patients heterozygous for familial hypercholesterolaemia, their relatives and unrelated controls. Arteriosclerosis Thromb 1991:11:940-6.

18 Seed M, Hoppichler F, Reaveley D, McCarthy S, Thompson GR, Boerwinkle E, et al. Relation of serum lipoprotein (a) concentration and apolipoprotein (a) phenotype to coronary heart disease in patients with familial hypercholesterolemia. N Engl J Med 1990:322:1494-9.

19 Dong W, Colhoun H, Lampe F. Blood analytes. In: Colhoun H, PrescottClarke P, eds. Health survey for England 1994. London: Stationery Office, 1996: 369-419.

20 Durrington PN. Hyperlipidaemia: diagnosis and management, 2nd ed. Oxford: Butterworth Heinemann, 1995.

21 Huggins GS, O'Gara PT. Clinical evaluation and diagnostic evaluation. In: Fuster V, Ross R, Topol EJ, eds. Atherosclerosis and coronary artery disease. Philadelphia: Lippincott-Raven, 1996;835-54

22 Goldman L, Goldman P, Williams LW, Weinstein MC. Cost-effectivenes considerations in the treatment of heterozygous familial hypercholesterolemia with medications. Am J Cardiol 1993;72:75-9D.

23 Irvine JM, Logan AG. Is knowing your cholesterol number harmful? Clin Epidemiol 1994;47:131-71.

24 Andersen LK, Jensen HK, Juul S, Faergeman O. Patients' attitudes towards detection of heterozygous familial hypercholesterolaemia. Arch Intern Med 1997;157:553-60.

(Accepted 26 September 2000)- 